UDC 811.111'25:34

DOI https://doi.org/10.32999/ksu2663-2691/2019-80-5

\title{
FEATURES OF ENGLISH LEGAL TERMS TRANSLATION
}

\author{
Hniedkova Olena Hennadiivna, \\ $P h D$ in Pedagogical Sciences, \\ Associate Professor at the Department of Foreign Philology \\ V. I. Vernadsky Taurida National University \\ elena.hniedkova@gmail.com \\ orcid.org/0000-0002-5419-4678
}

Bachurina Ludmila Vadimivna

Instructor at the Department of Foreign Philology

V. I. Vernadsky Taurida National University

bachurina2707@gmal.com

\begin{abstract}
The article deals with the current difficulties of legal terms translation. Nowadays the issue of accurate legal terms translation has become of utmost importance due to the integration of Ukraine into the world community. Consequently, legal terms translation faces many difficulties, as it should be adequate, clear and authentic. There is a need for translation transformations, in particular, lexical ones, since the language of the law has a specific vocabulary and certain terminological content.

The objective of the article is to study features of English legal terms being transmitted in Ukrainian.

The major methods applied in this research are the comperative analysis method of various Ukrainian and foreign authors' study works and of the legal texts chosen to exemplify the legal terms classifications, as well as the distributive and the descriptive methods.

The results of the research are defined as an overview of existing legal terms concepts, definitions and classifications as for terms structure and syntactical method of formation. At the same time, the article presents the Ukrainian traditional ways of legal translation, including examples in point.

Conclusions could be stipulated as follows. Despite its high relevance the translation process from English into Ukrainian still faces a number of difficulties accompanying it. They include both structural terms' peculiarities (simple, compound, termsword combinations) and requirements for the term to meet. Finally, often the equivalent of the term is determined by pragmatic

It should be noted that, despite the main ways of legal translation presented above, translators often face difficulties translating a particular term in a specific context which is to some extent determined by specific nature of legal terminology. The issue of adequate legal terms translation needs to be further studied.
\end{abstract} reasons.

Key words: legal terminology, translation challenges, legal terms' classification, legal concept, ways of translation.

\section{ОСОБЛИВОСТІ ПЕРЕКЛАДУ ЮРИДИЧНОЇ ТЕРМІНОЛОГІЇ В АНГЛІЙСЬКІЙ МОВІ}

\author{
Гнсдкова Олена Геннадіївна, \\ кандидат педагогічних наук, \\ дочент кафедри зарубіжної філології \\ Таврійського начіонального університету \\ імені B.I. Вернадського \\ elena.hniedkova@gmail.com \\ orcid.org/0000-0002-5419-4678
}

Бачуріна Людмила Вадимівна, викладач кафедри зарубіжної філологї Таврійського національного університету імені В.I. Вернадського

bachurina2707@gmal.com

\footnotetext{
Стаття присвячена особливостям перекладу юридичної термінології з англійської на українську мови. Сьогодні внаслідок інтеграції України в світову спільноту особливої важливості набуває питання точного перекладу юридичної термінології. Юридичний переклад правової документації являє собою непросте завдання, оскільки для адекватної передачі юридичної інформації мова юридичного перекладу повинна бути особливо точною, ясною і достовірною. Перед перекладачем постає проблема адекватної передачі змісту правових документів під час перекладу з однієї мови на іншу. Як наслідок виникає необхідність у перекладацьких трансформаціях, зокрема лексичних, оскільки мова права володіє особливою лексикою та має певне термінологічне наповнення.

Метою статті $є$ дослідження особливостей передачі юридичної термінології у процесі перекладу 3 англійської на українську мову.

Основними методами, застосованими в роботі, $є$ метод компаративного аналізу різноманітних досліджень вітчизняних та закордонних науковців, а також юридичних текстів, що містять приклади, які ілюструють класифікації юридичних термінів. Також використані дистрибутивний та дескриптивний методи.
} 
Результатами дослідження є огляд концепцій, що існують, визначень та класифікацій юридичних термінів із точки зору їхньої будови. У дослідженні розглянуті терміни, утворені синтаксичним способом, а також подані українські традиційні способи перекладу юридичних термінів із наведенням прикладів.

Висновки. Незважаючи на високу актуальність такого процесу, як переклад з англійської мови на українську, донині існує значний список складнощів, які супроводжують цей процес. До даних складнощів відносяться як структурні особливості термінів (прості, складні, терміни-сполучення), так і вимоги, яким має відповідати термін. Нарешті, часто еквівалент терміна визначається прагматичними причинами.

Слід зазначити, що, незважаючи на розглянуті вище основні способи перекладу термінів права, перекладачі нерідко стикаються із труднощами перекладу конкретного терміна в конкретному контексті, що деякою мірою зумовлено специфікою термінології. Подальшого вивчення потребує вивчення питання адекватності перекладу юридичних термінів.

Ключові слова: юридичні терміни, проблеми перекладу, класифікація юридичних термінів, поняття терміна, способи перекладу.

\section{Introduction}

The integration of Ukraine into the world community raises the issue of the importance of knowledge of terminology, reflecting legal concepts, not only by lawyers but also by translators. The translation of documents of individuals and legal entities can be characterised as "translation of texts related to the field of law and used to exchange legal information between people who speak different languages". Despite the considerable amount of research works into this problem, the number of scientific papers devoted to the study of features of legal terms translation is insufficient.

Problem statement. Since the law is a subject area connected to socio-political and cultural peculiarities of the country, legal documents translation is not an easy task. It is considered to be as one of the most difficult translations since the language of legal translation should be very accurate, clear and authentic to provide legal information adequately. An inadequately translated legal document could lead to misunderstandings and breaking contracts. Legal texts translation is one of the pressing problems of translation theory and practice, which is determined not only by the requirement to possess perfect knowledge of terminology, but also by the necessity to understand the linguistic realities of native speakers.

A translator faces the problem of adequate conveying of the content of legal documents while translating from one language to another. Consequently, there is a need for translation transformations, in particular, lexical ones, since the language of the law has a specific vocabulary and certain terminological content.

The relevance of our chosen topic is determined by the fact that the problem of translation of specific terminology, in particular legal, has not been covered enough by scientific literature. In particular, a system of rules providing support in translating specific legal terminology has not been developed yet.

Analysis of recent studies and publications. Legal translation emerged as a separate branch of professional translation studies in the late $80 \mathrm{~s}$ - early 90 s of the twentieth century. The legal translation difficulties was a subject of studies made by a number of Ukrainian and foreign scholars. The aspect of translation and interpretation of legal documents was investigated by such scientists as, S. Vlasenko, V. Karaban, L. Chernovaty, V. Vinogradov, A. Fedorov, V. Komisarov, V. Slepovich, R. Zorovchak, M. Korzhansky, T. Kiyak, M. Polyuzhin, E. Schepotina and others. Nevertheless, the issue of the adequacy of legal terms translation needs to be further studied.

The task of our article is to research the features of English legal terms translation.

The objective of the article is to study features of English legal terms being transmitted in Ukrainian.

\section{Difficulties of legal terms translation}

From ancient times, the translation of texts from one language to another has been one of the most important issues in applied philology. The development of science and technology has contributed to the emergence of sectoral terminologies. This, in its turn, resulted in the emergence of new features of translation, related directly to the search for equivalents for not just words of the common language, but for specific linguistic units - terms.

A.G. Anisimova pointed out that "the distinction between scientific and everyday interpretation of a concept and a word is fundamentally important for the study of terminologies and to a large extent for the terminology of the humanities. The terminological qualities of some humanities' terms are not sufficiently expressed and in some cases may not be observed at all" (Anisimova, 2002: 10). The author stresses that the main difference between the terms of the sciences and the humanities is the more specific nature of the former and, therefore, the less divergence in opinions of different scholars. Thus, the terms of the humanities are often characterized by instability due to the confrontation of opinions about their notions. S.V. Grinev draws attention to the fact that "the struggle between ideologies, as well as the subjective interpretation of concepts, lead to the emergence of emotional colour in terms". He also emphasizes that the most stable connotations can be kept, i.e. the term becomes independent of the context (Grinev-Grinevich, 2008: 54-55).

V.M. Leychik distinguishes two important concepts: "spontaneously comprised set of terms $<\ldots>$ can be called terminology and consciously formulated set of terms is a terminological system" (Lejchik, 2006: 105).

Thus, the term is an emotionally neutral word or a word combination that is used to accurately express the concepts and names of objects and has a well-defined definition. When translating legal terms from English into Ukrainian, the interaction of the term with the context is important, which makes the term more meaningful. (Shumylo I.I., Karpushyna M.H., 2017; 275-278).

From a theoretical point of view, the possibility to translate a term from one language to another means that the term in source language has a clear equivalent, i.e. invariant in the target language. At the same time, ideally neither the meaning nor the translation of the term should not depend on the context. However, completely different situation often occurs in practice: dictionaries provide numerous variants of translation for a term, which, of course, contradicts to the requirement 
of having one meaning. This is explained primarily by the fact that the terms of the humanities are often given an author's, individual understanding. And the choice of equivalent can depend on the context.

According to the Encyclopedic Legal Dictionary, legal terms are divided into three types based on their "comprehension" by one or another part of the population:

1. General terms are characterized by the fact that they are used in everyday life and understood by all. This group includes, for example, refugee, witness, employee, accomplice, accreditation. 2. Special legal terms possess a specific legal content (and, apparently, are not understood by all, but only by experts in the field of law). They include, for example: necessary defence, claim satisfaction; coerced acquiescence, this retaliate accusation. 3. Special technical terms reflect the area of specialized knowledge - technology, economics, medicine, etc. (apparently, these terms should be understood by a lawyer specializing in another field as well). They include, for example, defective products, safety rules, non-patentable, nuclear-free (Encyclopedic Legal Dictionary, 2001).

The emergence of new branches of law and the discovery of new phenomena entails considerable difficulties in defining general scientific, general technical sectoral and specialized terminology. General scientific and general technical terms are terms used in several fields of science and technology.

Sectoral terms are terms that are used only in one branch of knowledge.

For example, legal rules, adopted the law, nugatory.

Specific terms are terms that relate to the speciality of a particular sector. For example, lawsuit, nunciature, chaplain, charge-sheet (Mostovyi, 1993: 182-185).

In general, there are different theories as to how terms can be translated. "Western science offers several methods of translating terms that have specific connotations of the relevant foreign language: the use of a functional equivalent inherent in the cultural and linguistic traditions of the country (cultural / functional equivalent); literal translation of each word (translating literally/word by word); borrowing the original term of the source language (transcribing (i.e. borrowing the SL term)); creation of neologism (neologising)" (Anisimova, 2002: 139-143).

\section{The Ukrainian tradition includes the following ways of terms translating}

The Ukrainian tradition includes the following ways of terms translating:

1) translation based on lexical equivalent, for example: legal case - судова справа, forensic medical examination судово-медична експертиза, common law - загальне право, family law, family law - ciмейне право, corporal punishment - тілесне покарання; assassin - убивця);

2) calque - the reproduction of not a sound but a combinatorial composition of a word or word combination, when the constituent parts of a word (morpheme) or phrases (lexeme) are translated by the relevant elements of language, for example: accomplice of attempt - співучасник у замаху на життя; according to law - відповідно до закону, тultiple accredit - множинне акредитування;

3) transcription - the formal reproduction of the original lexical unit with the help of language of translation phonemes, for example: securitization, lex scripta - писаний закон, ultra vires - поза компетенцією або за межами повноважень;

4) transliteration - the formal reproduction of the original lexical unit using the language of translation alphabet, for example: solicitor - солиситор, barrister - барристер, legitimism - легитимизм, vice-chancellor - віце-канцлер, viceconsul - вице-консул);

5) descriptive translation is a lexico-grammatical transformation whereby the lexical unit of the source language is replaced by explaining or defining word combination, for example: official accusation - офіційне звинувачення (у здійсненні злочину);

6) approximate translation - when translating basic meaning of the word is retained, but its meaning in target language differs from that of the source language by lexical background, for example: police photographer - судовий фотограф, notary public - державний нотарiус;

7) translation using analogue - when one of several possible synonyms are used, for example: claim - позов, праводомагання, претензія, вимога; notice - попередження, повідомлення, заява, сповіщення, попереджати, заявляти сповіщати; сповіщення про готовність судна до завантаження; нотіс; знання, обізнаність;

8) neologizing translation. A neologism in legal linquistics implies the presence of a word or word combination that does not exist in the legal system of the target language, for example: stay-in - пікетування; has-been - політичний діяч, який утратив свій вплив (Karaban, 2004: 472).

We can often come across cases of combination of these transformations when translating one terminological unit. Due to some differences in the grammatical, syntactic and morphological structures of English and Ukrainian languages, the translator should use various transformations.

According to the theory proposed by V.N. Komisarov as for their structure, all terms can be divided into three groups:

1. Simple, consisting of one word: punish - наказати.

2. Compound, consisting of two words and written as a single word or hyphenated: the High Соurt - Високий суд.

3. Terms - word combinations, consisting of several components: specific performance - реальне виконання (Котіsarov, 2008: 83).

Since legal terms are mainly presented by terms-word combinations, their translation is considered to be a major problem.

In the framework of legal terminology there is a significant number of terms, formed by the syntactical method. As for the number of components we can distinguish: 1) two-component terms, such as юридична практика, кримінальне судочинство, nonprejudicial character, law charge; 
2) three-component - загальнодержавне адвокатське об'єднання, організоване злочинне формування, јudge's finish charge;

3) poly-component - добровільна відмова від вчинення замаху на злочин; спроба застосування вогнепальної зброї; to acknowledge recognizance in false name, acquisition by discovery and occupation (Kaliuzhna, 1982: 47).

M.I. Mostovy emphasizes that the legal term should meet the following requirements:

1. The term should be as short and accurate as possible. And the term is not just a label; it must clearly and to full extent convey the characteristics of the concept. Not all the terms describe a structure, anomaly, process, or function, but in general, each term has brief indicative or descriptive characteristics.

2. Specific nature. This feature is a very desirable quality for the term in every field of science. Ideally, the terminological name should be unambiguous within the specific field terminology and not have synonyms.

The term is also required to be emotionally neutral, targeted on an object in the system or set and conform to the word-forming language regularities. At the same time, the term is required to serve as a ground for derivatives, but only within its own system (Mostovyi, 1993: 187).

\section{Conclusions}

Despite its high relevance the translation process from English into Ukrainian still faces a number of difficulties accompanying it. They include both structural terms' peculiarities (simple, compound, terms-word combinations) and requirements for the term to meet. Finally, often the equivalent of the term is determined by pragmatic reasons.

It should be noted that, despite the main ways of legal translation presented above, translators often face difficulties translating a particular term in a specific context which is to some extent determined by specific nature of legal terminology. Besides, the complete list of fixed expressions to be used while translating such units has not been developed yet. Finally, legal terminology is developing its spectrum and is being replenished with a big number of new terms which do not have any translation equivalents that is a problem for the translator. The issue of adequate legal terms translation needs to be further studied.

\section{Bibliography:}

1. Анисимова А.Г. К вопросу о переводе терминов гуманитарных наук / Язык. Сознание. Коммуникация : сб. статей / отв. ред. В.В. Красных, А.И. Изотов. Москва : МАКС Пресс, 2002. Вып. 21. С. 139-143.

2. Гринев-Гриневич С.В. Терминоведение. Москва : Академия, 2008. 304 с.

3. Лейчик В.М. Терминоведение : предмет, методы, структура. Москва : Либроком, 2006. 256 с.

4. Шумило I.I., Карпушина М.Г. Труднощі перекладу юридичних термінів англійської мови. Молодий вчений. № 12(52) грудень, 2017 С. 275-278. С. 276.

5. Енциклопедичний юридичний словник. Київ, 2001.

6. Мостовий М.І. Лексикологія англійської мови. Харків : Основа, 1993. 256 с.

7. Карабан В.І. Переклад англійської наукової і технічної літератури: Граматичні труднощі, лексичні, термінологічні та жанрово-стилістичні проблеми. Вінниця : Нова Книга, 2004. 576 с.

8. Комисаров В.Н. Лингвистика перевода. Москва : Международные отношения, 1980. 167 с.

9. Калюжна В.В. Стиль англомовніх документів. Київ : Наукова думка, 1982. 120 с.

\section{References:}

1. Anisimova A.G. (2002). K voprosu o perevode terminov gumanitarny $h$ nauk. [As for translating the terms of the humanities] / A. G. Anisimova // Yazy`k. Soznanie. Kommunikaciya : sb. statej / otv. red. V. V. Krasny`h, A. I. Izotov. Moskva : MAKS Press, Vy`p. 21, 139-143 [in Russian].

2. Grinev-Grinevich S.V. (2008). Terminovedenie. [Terminology studies]/S.V.Grinev-Grinevich. Moskva: Akademiya, 304 [in Russian].

3. Lejchik V.M. (2006). Terminovedenie: predmet, metody', struktura. [Terminology studies: subject, methods, structure]/ V. M. Lejchik. Moskva: Librokom, 256 [in Russian].

4. Shumylo I.I., Karpushyna M.H. (2017). Trudnoshchi perekladu yurydychnykh terminiv anhliiskoi movy. [Difficulties in translating English legal terms]. Young Scientist. №12 (52) December 2017, p. 275-278 p. 276. [in Ukrainian].

5. Entsyklopedychnyi yurydychnyi slovnyk. (2001). [Encyclopedic Legal Dictionary]. Kyiv.

6. Mostovyi M.I. (1993). Leksykolohiia anhliiskoi movy. [Lexicology of English]. Kharkiv: Osnova, 256 [in Ukrainian].

7. Karaban V.I. (2004). Pereklad anhliiskoi naukovoi i tekhnichnoi literatury: Hramatychni trudnoshchi, leksychni, terminolohichni ta zhanrovo-stylistychni problemy. [Translation of English Scientific and Technical Literature: Grammatical difficulties, lexical, terminological and genre-stylistic problems]/ V. I. Karaban. Vinnytsia: Nova Knyha, 576 [in Ukrainian].

8. Komisarov V.N. (1980). Lingvistika perevoda. [Linguistics of Translation]/V. N. Komisarov. Moskva: Mezhdunarodny`e otnosheniya, 167 [in Russian].

9. Kaliuzhna V.V. (1982). Styl anhlomovnikh dokumentiv. [Style of English documents]. Kyiv: Naukova dumka, 120 [in Ukrainian]. 